Pobrane z czasopisma Annales H - Oeconomia http://oeconomia.annales.umcs.pl Data: 26/04/2023 08:53:44

DOI:10.17951/h.2018.52.4.123-132

\begin{tabular}{lcl}
\hline \multicolumn{2}{c}{ A N N A L E S } \\
UNIVERSITATIS MARIAE CURIE-SKŁODOWSKA \\
LUBLIN - POLONIA \\
VOL. LII, 4 \\
SECTIO H
\end{tabular}

Szkoła Główna Handlowa. Kolegium Zarządzania i Finansów

JOANNA SZLĘZAK-MATUSEWICZ

ORCID ID: https://orcid.org/0000-0003-2017-9434

joanna.szlezak@sgh.waw.pl

\title{
Optymalizacja opodatkowania działów specjalnych produkcji rolnej
}

Tax Optimization of Special Branches of Agricultural Production

Słowa kluczowe: działy specjalne produkcji rolnej; optymalizacja podatkowa; opodatkowanie rolnictwa Keywords: special branches of agricultural production; tax optimization; taxation of agriculture

Kod JEL: H26; K34; Q14

\section{Wstęp}

Cechą charakterystyczną opodatkowania działalności rolniczej jest jego wyodrębnienie z powszechnego systemu podatkowego. Podatkiem obciążającym gospodarstwa rolne jest podatek rolny, którego wymiar zależy przede wszystkim od wartości użytkowej ziemi. Dochody z rolnictwa nie podlegają więc opodatkowaniu podatkiem dochodowym. Wyjątek stanowią tzw. działy specjalne produkcji rolnej. Cechą odróżniającą je od pozostałej działalności rolniczej jest przede wszystkim to, że dotyczą specjalistycznej produkcji, hodowli lub chowu. Są to np. uprawy roślin in vitro czy hodowla i chów zwierząt futerkowych. Bieluk wskazuje, że działy specjalne znalazły się gdzieś pomiędzy typową działalnością rolniczą a nierolniczą działalnością gospodarczą [Bieluk, 2013, s. 18]. Na gruncie podatku dochodowego od osób fizycznych [Ustawa z dnia 26 lipca 1991 r. o podatku dochodowym od osób fizycznych, dalej jako: u.p.d.o.f.] stanowią one odrębne źródło przychodów (art. 10 
ust. 1 pkt 4 u.p.d.o.f.), które może być opodatkowane na dwa sposoby: w oparciu o dochód rzeczywisty lub w oparciu o dochód szacunkowy.

Począwszy od 2016 r., nastąpiła zmiana przepisów w zakresie opodatkowania działów specjalnych produkcji rolnej. Działalność ta została objęta wymogiem prowadzenia ksiąg rachunkowych w sytuacji osiągnięcia wielkości przychodów określonej w przepisach o rachunkowości [Ustawa z dnia 29 września 1994 r. o rachunkowości, dalej jako: u.o.r.]. W praktyce oznacza to nie tylko obowiązek ponoszenia wyższych kosztów związanych z obsługą księgową, ale przede wszystkim utratę możliwości ustalania dochodu w oparciu o normy szacunkowe, które stanowią pewnego rodzaju preferencję podatkową. Podatnicy starają się więc $\mathrm{w}$ ramach obowiązującego prawa uniknąć obowiązku prowadzenia ksiąg rachunkowych.

Celem artykułu jest wskazanie możliwości optymalizacji opodatkowania działów specjalnych produkcji rolnej i ryzyk związanych z działaniem podatników w tym zakresie. Osiągnięcie przyjętego celu będzie możliwe dzięki analizie konstrukcji prawnych ustawy o podatku dochodowym od osób fizycznych ${ }^{1}$ i ustawy o rachunkowości oraz orzecznictwa organów podatkowych i sądów administracyjnych.

\section{Pojęcie działów specjalnych i ich opodatkowanie na gruncie podatków dochodowych}

Ustawa o podatku dochodowym od osób fizycznych wyłącza z opodatkowania przychody z działalności rolniczej ${ }^{2} \mathrm{z}$ wyjątkiem działów specjalnych produkcji rolnej (art. 2 ust. 1 pkt 1 u.p.d.o.f.). Przychody z działów specjalnych produkcji rolnej podlegają więc opodatkowaniu podatkami dochodowymi. Działami specjalnymi produkcji rolnej zgodnie z u.p.d.o.f. są: uprawy w szklarniach i ogrzewanych tunelach foliowych; uprawy grzybów i ich grzybni; uprawy roślin in vitro; fermowa hodowla i chów drobiu rzeźnego i nieśnego; wylęgarnie drobiu; hodowla i chów zwierząt futerkowych i laboratoryjnych; hodowla dżdżownic; hodowla entomofagów; hodowla jedwabników; prowadzenie pasiek; hodowla i chów innych zwierząt poza gospodarstwem rolnym (art. 2 ust. 3 u.p.d.o.f.). Nie stanowią działów specjalnych produkcji rolnej uprawy, hodowla i chów zwierząt w rozmiarach nieprzekraczających wielkości określonych w załączniku nr $2^{3}$ (art. 2 ust. 3a u.p.d.o.f.).

$1 \mathrm{Z}$ uwagi na podobne regulacje $\mathrm{w}$ zakresie opodatkowania działów specjalnych produkcji rolnej w ustawie o podatku dochodowym od osób fizycznych i ustawie o podatku dochodowym od osób prawnych w dalszej części rozważań autorka będzie się odnosić wyłącznie do przepisów ustawy o podatku dochodowym od osób fizycznych.

2 Ustawa o podatku dochodowym od osób fizycznych zawiera własną definicję działalności rolniczej (por. art. 2 ust. 2 u.p.d.o.f.).

3 Tabela rodzajów i rozmiarów działów specjalnych produkcji rolnej oraz norm szacunkowych dochodu rocznego. 
Wyznaczając ramy pojęciowe działów specjalnych produkcji rolnej, należy poczynić kilka uwag. Po pierwsze, jak zauważa Bieluk, zakres definicji działów specjalnych produkcji rolnej powinien zawierać się w definicji działalności rolniczej [Bieluk, 2013, s. 140]. Po drugie, działalność rolniczą (opodatkowaną podatkiem rolnym) od działów specjalnych produkcji rolnej różni przede wszystkim zakres działalności i jej rozmiar. Jak bowiem zauważył skład orzekający NSA w wyroku z dnia 17 czerwca 2009 r. (II FSK 289/08), ,czynnikiem rozróżniającym jest rozmiar prowadzonej działalności, co wyraźnie wynika z art. 2 ust. 3a u.p.d.o.f. Zatem, aby móc zwolnić się z opodatkowania podatkiem dochodowym od osób fizycznych, należy wykazać, że rozmiar tej produkcji nie przekracza norm ustalonych dla produkcji rolnej w ramach tak zwanych działów specjalnych". Rodzaj i rozmiary działów specjalnych produkcji rolnej określa załącznik nr 2 do u.p.d.o.f. Opodatkowaniem podatkiem dochodowym podlega tylko ta działalność, która spełnia jednocześnie dwa warunki: została wymieniona w załączniku nr 2 do u.p.d.o.f. i jej rozmiary przekraczają wielkości określone w tym załączniku.

Analizując treść załącznika nr 2, można stwierdzić, że za działy specjalne produkcji rolnej uznano wyłącznie te rodzaje produkcji, których prowadzenie nie jest uzależnione od warunków klimatycznych i glebowych [Dziemianowicz, 2007, s. 301]. Z kolei Bieluk wskazuje, że działy specjalne to działalność niezależna od gruntów [Bieluk, 2013, s. 346]. Są nimi m.in. uprawy w szklarniach ogrzewanych powyżej $25 \mathrm{~m}^{2}$, drób rzeźny powyżej 100 szt., pasieki powyżej 80 rodzin.

\section{Opodatkowanie działów specjalnych produkcji rolnej}

Dochody uzyskiwane z prowadzenia działów specjalnych produkcji rolnej są opodatkowane podatkiem dochodowym, przy czym ustawodawca przewidział dwie formy ustalania dochodu dla celów podatkowych: w oparciu o przychody i koszty rzeczywiste oraz w oparciu o tzw. normy szacunkowe.

W świetle art. 24 ust. 4 u.p.d.o.f., jeżeli podatnik nie prowadzi ksiąg, dochód ustala się przy zastosowaniu norm szacunkowych z określonej powierzchni upraw lub jednostki produkcji zwierzęcej, określonych w załączniku nr 2 do u.p.d.o.f. Jest to tzw. dochód szacunkowy. Podstawę opodatkowania, obliczoną przy zastosowaniu norm szacunkowych dochodu, stanowi dochód wynikający z iloczynu właściwej dla danego rodzaju produkcji działu specjalnego normy szacunkowej dochodu i ilości jednostek produkcji, których ta norma dotyczy. Podatek dochodowy od tak ustalonego dochodu oblicza się według progresywnej skali podatkowej (art. 27 ust. 1 u.p.d.o.f.). W tej konstrukcji ustalania dochodu nie ma możliwości zastosowania stawki liniowej (19\%).

Podatnicy mogą ustalać dochód także w oparciu o przychody i koszty rzeczywiste (art. 15 u.p.d.o.f.). Jest to jednak możliwe tylko wtedy, gdy podatnik prowadzi księgi rachunkowe lub podatkową księgę przychodów i rozchodów. W przypadku 
rozpoczęcia prowadzenia podatkowej księgi przychodów i rozchodów podatnik jest zobowiązany zawiadomić właściwego naczelnika urzędu skarbowego przed rozpoczęciem roku podatkowego albo przed rozpoczęciem prowadzenia działów specjalnych produkcji rolnej, jeżeli nastąpiło to w ciągu roku. W przypadku obowiązku prowadzenia ksiąg rachunkowych, wynikającego z ustawy o rachunkowości, nie ma konieczności zawiadomienia właściwego naczelnika urzędu skarbowego o założeniu tych ksiąg. Wybór odpowiedniej formuły ewidencji zależy w dużej mierze od obowiązków wynikających z ustawy o rachunkowości (art. 15 ust. 2 u.p.d.o.f.).

Swoboda w zakresie wyboru formy określania dochodu obowiązywała do końca 2015 r. Jak wynika z danych Ministerstwa Finansów, do końca 2015 r. ponad 99\% podatników określało dochód przy zastosowaniu metody szacunkowej (tab. 1). Przyczyn tego należy upatrywać przede wszystkim w:

- niższym obciążeniu podatkowym z tytułu podatku dochodowego w porównaniu z obciążeniem, jakie wynikałoby z dochodu rzeczywistego. Warto podkreślić, że normy szacunkowe nie były zmieniane od ponad 20 lat. Poza tym określają one dochód do opodatkowania, który nie ma nic wspólnego z faktycznym wynikiem finansowym podatnika,

- niższych kosztach związanych z obsługą księgową (podatnicy nie są zobligowani do prowadzenia ksiąg podatkowych).

Tab. 1. Liczba podatników prowadzących działy specjalne produkcji rolnej w latach 2011-2016

\begin{tabular}{|c|c|c|c|c|c|}
\hline \multirow[b]{2}{*}{ Rok } & \multirow[b]{2}{*}{ Ogółem } & \multicolumn{3}{|c|}{ Podatnicy ustalający dochód na podstawie ksiąg } & \multirow{2}{*}{$\begin{array}{l}\text { Podatnicy ustalający dochód } \\
\text { przy zastosowaniu norm } \\
\text { szacunkowych dochodu } \\
\text { z określonej powierzchni } \\
\text { upraw lub jednostki produkcji } \\
\text { zwierzęcej }\end{array}$} \\
\hline & & Ogółem & $\begin{array}{l}\text { Na podstawie ksiąg } \\
\text { rachunkowych }\end{array}$ & $\begin{array}{l}\text { Na podstawie } \\
\text { księgi przychodów } \\
\text { i rozchodów }\end{array}$ & \\
\hline 2011 & 31484 & 240 & 117 & 123 & 31244 \\
\hline 2012 & 31650 & 266 & 83 & 183 & 31384 \\
\hline 2013 & 31623 & 181 & 77 & 104 & 31442 \\
\hline 2014 & 31775 & 171 & 77 & 94 & 31604 \\
\hline 2015 & 32227 & 148 & 62 & 86 & 32079 \\
\hline 2016 & 33300 & 858 & 342 & 516 & 32442 \\
\hline
\end{tabular}

Źródło: dane uzyskane z Ministerstwa Finansów.

Z dniem 1 stycznia 2016 r. ustawodawca znowelizował art. 15 ustawy o PIT [Ustawa z dnia 9 kwietnia 2015 r. o zmianie ustawy o podatku dochodowym od osób fizycznych oraz niektórych innych ustaw]. Nowy ust. 2 art. 15 stanowi, że gdy obowiązek prowadzenia ksiąg rachunkowych wynika z przepisów o rachunkowości, przychód z działów specjalnych produkcji rolnej ustala się na podstawie prowadzonych ksiąg rachunkowych według zasad określonych w art. 14 (zasad właściwych dla pozarolniczej działalności gospodarczej). W takim przypadku nie ma obowiązku zawiadomienia właściwego naczelnika urzędu skarbowego o założeniu ksiąg 
rachunkowych. Uzasadnienie wprowadzenia nowych przepisów można znaleźć w odpowiedzi na interpelację poselską, w której Minister Rolnictwa i Rozwoju Wsi stwierdziła, że:

[...] nieuzasadnione było utrzymywanie stanu prawnego, zgodnie z którym osoby, które prowadzą księgi rachunkowe, ponieważ obligują je do tego przepisy o rachunkowości i tym samym dysponują danymi do ustalenia rzeczywistego dochodu z działów specjalnych produkcji rolnej, dla celów podatku dochodowego ustalają dochód w sposób zryczałtowany, tj. na podstawie norm szacunkowych dochodu. Racjonalnym jest, żeby osoby takie płaciły podatek dochodowy od rzeczywistego dochodu osiąganego z działów specjalnych produkcji rolnej [Odpowiedź na interpelację nr 33692 z dnia 26 sierpnia 2015 r.].

Przepisy obowiązujące od początku 2016 r. nakładają na rolników obowiązek prowadzenia ksiąg rachunkowych, jeżeli ich przychody netto ze sprzedaży towarów, produktów i operacji finansowych za poprzedni rok obrotowy wyniosły co najmniej równowartość w walucie polskiej $2 \mathrm{mln}$ euro (w $2016 \mathrm{r}$. była to kwota 1,2 mln euro).

Osiągnięcie relatywnie wysokich przychodów przez podatnika prowadzącego działy specjalne produkcji rolnej oznacza w praktyce nie tylko obowiązek prowadzenia ksiąg rachunkowych na podstawie ustawy o rachunkowości, ale przede wszystkim utratę możliwości ustalania dochodu w oparciu o normy szacunkowe. Z kolei wykazywanie dochodu rzeczywistego na podstawie prowadzonych ksiąg oznacza konieczność jego opodatkowania na zasadach ogólnych - przy zastosowaniu skali progresywnej lub stawki liniowej. Obciążenie to zazwyczaj jest znacznie wyższe w porównaniu z opodatkowaniem dochodu szacunkowego.

Z danych Ministerstwa Finansów wynika, że liczba podatników ustalających dochód na podstawie ksiąg (zarówno podatkowej księgi przychodów i rozchodów, jak i ksiąg rachunkowych) wzrosła ze 148 w 2015 r. do 858 w 2016 r. Patrząc na wszystkich podatników prowadzących działy specjalne produkcji rolnej, wzrost ten jest jednak praktycznie niezauważalny (z $0,45 \%$ do $2,57 \%$ ). Mimo wprowadzenia obowiązku, który finalnie miał się przełożyć na wyższe obciążenia podatkowe i tym samym wyższe dochody budżetowe, pozostał on bez znaczenia fiskalnego. Jedną z przyczyn takiego stanu rzeczy mogą być działania optymalizacyjne podejmowane przez podatników. Szukają oni w ramach legalnych rozwiązań różnych sposobów pozwalających na uniknięcie stosowania przepisów o rachunkowości. Optymalizacja podatkowa jest działaniem zgodnym z prawem, polegającym na wyborze takiego sposobu postępowania, którego celem jest maksymalizacja zysku netto poprzez minimalizację obciążeń podatkowych [Szlęzak-Matusewicz, 2013, s. 17].

Można wskazać co najmniej dwa modele stosowane przez podatników. Pierwszy to prowadzenie działalności rolniczej indywidualnie i w ramach spółki osobowej, a drugi - prowadzenie działalności poprzez rodzinne gospodarstwo rolne. 


\section{Prowadzenie działów specjalnych indywidualnie i w ramach spólki osobowej}

Obowiązek prowadzenia ksiąg rachunkowych wynikający z ustawy o rachunkowości dotyczy tych podatników, których przychody przekroczyły określony w przepisach próg $2 \mathrm{mln}$ euro. Istotne jest więc pytanie, czy prowadzenie działalności w różnych formach ma wpływ na obowiązek prowadzenia ksiąg rachunkowych. Jako przykład można wskazać działalność prowadzoną przez podatnika samodzielnie oraz jako wspólnika spółki osobowej. W takiej sytuacji limit przychodów dotyczy odrębnie działalności samodzielnej i odrębnie działalności prowadzonej przez spółkę. Bez znaczenia dla obowiązku prowadzenia ksiąg pozostaje fakt, że łączny przychód (z działalności samodzielnej i w spółce, przypadający na podatnika) przekroczy graniczną kwotę $2 \mathrm{mln}$ euro. Zasadniczą kwestią wymagającą wyjaśnienia w kontekście postawionej tezy jest sposób liczenia limitu przychodów, o którym jest mowa w ustawie o rachunkowości, w sytuacji prowadzenia działalności w różnych formach - indywidualnie oraz w spółce osobowej.

Przepisy ustawy o rachunkowości stosuje się do osób fizycznych, spółek cywilnych osób fizycznych, spółek jawnych osób fizycznych oraz spółek partnerskich, których przychody netto ze sprzedaży towarów, produktów i operacji finansowych za poprzedni rok obrotowy wyniosły co najmniej równowartość w walucie polskiej 2 mln euro, a także do spółek komandytowych - bez określania kwoty limitu. Należy przy tym zauważyć, że podmiotowość prawnobilansową, a zatem również obowiązek prowadzenia ksiąg podatkowych, posiadają spółki jawne osób fizycznych lub spółki cywilne osób fizycznych prowadzących pozarolniczą działalność gospodarczą, a nie wspólnicy tych spółek, co oznacza, że limit, o którym mowa w przepisach rachunkowych, jest ustalany odrębnie dla każdej spółki. Analogicznie jest w przypadku spółki komandytowej - podmiotowość prawnopodatkową posiada spółka, a nie jej wspólnicy (art. 2 ust. 1 pkt 1-2 u.o.r.).

W praktyce oznacza to, że jeżeli osoba fizyczna prowadzi działy specjalne produkcji rolnej indywidualnie oraz w spółce, to limit przychodów należy ustalać odrębnie dla działalności prowadzonej indywidualnie i działalności prowadzonej w spółce. Oznacza to, że ta sama osoba fizyczna (występująca w obrocie gospodarczym indywidualnie oraz jako wspólnik spółki osobowej) może być zobowiązana do ustalenia przychodu osiągniętego z działów specjalnych produkcji rolnej na zasadach określonych w art. 14 ustawy o podatku dochodowym (np. jako wspólnik spółki osobowej prowadzącej księgi rachunkowe) oraz przy zastosowaniu norm szacunkowych $\mathrm{w}$ związku z działami specjalnymi prowadzonymi indywidualnie.

Taką wykładnię potwierdzają interpretacje indywidualne wydawane przez Krajową Informację Skarbową [Interpretacja indywidualna z dnia 12 września 2017 r.; Interpretacja indywidualna $z$ dnia 20 maja 2016 r.]. W interpretacji indywidualnej z dnia 2 października 2017 r. wskazano: „Na sumę przychodów, czy też obowiązki Wnioskodawcy w zakresie prowadzenia ksiąg, nie mają wpływu przychody osią- 
gnięte przez Wnioskodawcę z tytułu udziału w spółce osobowej, która również prowadzić będzie działy specjalne produkcji rolnej”. Z kolei w interpretacji indywidualnej z dnia 12 września 2017 r. znajduje się stwierdzenie: „Wnioskodawca będzie miał możliwość opodatkowania dochodów uzyskanych z prowadzonej samodzielnie działalności stanowiącej działy specjalne produkcji rolnej według norm szacunkowych, mimo że Nowa Spółka (której Wnioskodawca będzie wspólnikiem) dobrowolnie lub obowiązkowo - będzie prowadzić księgi rachunkowe, zgodnie $\mathrm{z}$ art. 14 ww. ustawy".

Zastosowanie dwóch różnych reżimów podatkowych w stosunku do tej samej osoby jest niezwykle korzystne dla podatnika, ponieważ może tak ukształtować strukturę swoich przychodów i kosztów, aby zobowiązanie podatkowe było jak najniższe.

\section{Prowadzenie działów specjalnych poprzez rodzinne gospodarstwo rolne}

Rodzinne gospodarstwo rolne jest pojęciem zdefiniowanym w ustawie z dnia 11 kwietnia 2003 r. o kształtowaniu ustroju rolnego. Gospodarstwem rodzinnym jest gospodarstwo rolne prowadzone przez rolnika indywidualnego, w którym łączna powierzchnia użytków rolnych jest nie większa niż 300 ha. Z punktu widzenia rolnika prowadzącego działy specjalne istotne jest więc posiadanie gospodarstwa rolnego o określonej wielkości - nie mniejszego niż 1 ha, ale nie większego niż 300 ha. Puślecki podkreśla, że w literaturze ekonomicznej jako główne wyróżniki gospodarstwa rodzinnego przyjmuje się korzystanie z rodzinnych zasobów pracy, zarządzanie gospodarstwem przez członka rodziny, wielkość posiadanego gospodarstwa lub wielkość wytwarzanej produkcji rolnej [Puślecki, 2016, s. 223].

Zasady ustalania limitu w przypadku rodzinnych gospodarstw rolnych są odmienne niż w przypadku spółek. O ile w tym ostatnim podmiotowość prawnopodatkową ma spółka, o tyle w rodzinnych gospodarstwach rolnych taką podmiotowość ma rolnik, a nie gospodarstwo. Przekładając to na grunt rachunkowo-podatkowy, należy odnotować, że dla obowiązku prowadzenia ksiąg rachunkowych znaczenie będzie mieć odrębne osiągnięcie limitu przychodów przez każdego członka rodziny prowadzącego gospodarstwo rolne. Tezy te potwierdzają wydawane w tym zakresie interpretacje indywidualne: „Rodzinne gospodarstwo rolne nie jest żadną ze spółek wymienionych w art. 2 ust. 1 pkt 2 ustawy o rachunkowości, zatem obowiązek prowadzenia ksiąg rachunkowych może odnosić się tylko do osób fizycznych prowadzących rodzinne gospodarstwo rolne, a nie do samego rodzinnego gospodarstwa rolnego" [Interpretacja indywidualna z dnia 27 stycznia 2016 r.; zob. także: Interpretacja indywidualna $z$ dnia 8 grudnia 2017 r.]. Im więcej członków rodziny jest zaangażowanych $\mathrm{w}$ prowadzenie działalności $\mathrm{w}$ formie rodzinnego gospodarstwa rolnego, tym mniejsze jest prawdopodobieństwo osiągnięcia limitu przychodów określonego w ustawie o rachunkowości. 


\section{Granice optymalizacji podatkowej}

Zastosowanie opisanych modeli optymalizacji podatkowej ma na celu przyjęcie korzystnego dla podatnika sposobu liczenia limitu przychodów wyznaczonego przez przepisy rachunkowe. W praktyce nieosiągnięcie tego limitu powoduje: eliminację obowiązku prowadzenia ksiąg rachunkowych, zachowanie prawa do ustalania dochodu metodą szacunkową oraz w rezultacie niższe obciążenie podatkowe.

Trzeba jednak pamiętać, że działanie takie - mimo że istnieją w obrocie prawnym pozytywne dla konkretnych podatników indywidualne interpretacje podatkowe - nie zawsze w przypadku pozostałych podatników może być akceptowalne przez organy podatkowe. W działanie optymalizacji podatkowej zawsze jest wpisany element ryzyka [Szlęzak-Matusewicz, 2008, s. 48]. Może ono dotyczyć prawnych granic optymalizacji podatkowej, które są obecnie wyznaczane w oparciu o przepisy klauzuli przeciwko unikaniu opodatkowania. Klauzula ta została wprowadzona do przepisów Ordynacji podatkowej w lipcu 2016 r. (Ustawa z dnia 29 sierpnia 1997 r. - Ordynacja podatkowa, art. 119a-1191). Wyznacza ona granicę między działaniami w pełni legalnymi (zgodnymi z przepisami i celem ustawy) a działaniami nielegalnymi (zgodnymi z przepisami ustawy, lecz niezgodnymi z jej celem - nadużycie prawa podatkowego). Jeżeli podatnik podejmuje czynność (lub szereg różnych czynności pomiędzy różnymi podmiotami) w celu osiągnięcia korzyści podatkowej, sprzeczną w danych okolicznościach z przedmiotem i celem przepisu ustawy, a sposób działania podatnika jest sztuczny, to czynność ta nie skutkuje osiągnięciem korzyści ${ }^{4}$. Przy ocenie, czy sposób działania podatnika był sztuczny, należy wziąć pod uwagę w szczególności występowanie m.in. nieuzasadnionego dzielenia operacji lub angażowania podmiotów pośredniczących mimo braku uzasadnienia ekonomicznego lub gospodarczego. Stosując opisane modele optymalizacji podatkowej, należy pamiętać, że jeżeli podatnik np. sztucznie dzieli działalność na różne formy prawne, bez żadnego uzasadnienia ekonomicznego, może się narazić na zarzut nadużycia prawa podatkowego. Oczywiście jednoznaczne określenie, czy dane działanie stanowi działanie legalne czy nielegalne ( $w$ sensie jego postrzegania przez pryzmat klauzuli), będzie wymagało wnikliwej analizy stanu faktycznego i niewątpliwie może być przedmiotem sporu między podatnikiem i organem podatkowym.

4 Klauzuli się nie stosuje, jeżeli korzyść podatkowa lub suma korzyści podatkowych osiągniętych przez podmiot z tytułu czynności nie przekracza w okresie rozliczeniowym 100 tys. zł, a w przypadku podatków, które nie są rozliczane okresowo - jeżeli korzyść podatkowa z tytułu czynności nie przekracza 100 tys. zł. 


\section{Podsumowanie}

Działy specjalne produkcji rolnej są podatkowym określeniem specyficznej działalności rolniczej. Podlegają one opodatkowaniu podatkiem dochodowym. Podobnie jak w przypadku innych źródeł, przedmiotem opodatkowania jest tutaj dochód. Jednak szacunkowa metoda jego ustalania sprawia, że obciążenie podatkowe przybiera w rzeczywistości formę ryczałtu niezależnego od faktycznych wyników finansowych podatnika. Próba objęcia od 2016 r. podatników o najwyższych dochodach ogólnymi zasadami ustalania dochodu w rzeczywistości się nie powiodła. Przepisy, choć istnieją, w praktyce są stosowane przez niewielki odsetek podatników. Można bowiem stosować różne formy optymalizacji podatkowej. Kwestią zasadniczą jest pytanie o cel działań optymalizacyjnych - jeżeli brak jest w nich uzasadnienia ekonomicznego, wówczas istnieje ryzyko ich zakwestionowania przez organ podatkowy.

\section{Bibliografia}

Bieluk J., Działy specjalne produkcji rolnej. Problemy prawne, Temida 2, Białystok 2013.

Dziemianowicz R., Efektywność systemu opodatkowania rolnictwa, Wydawnictwo Uniwersytetu w Białymstoku, Białystok 2007.

Interpretacja indywidualna z dnia 27 stycznia 2016 r., IPTPB1/4511-702/15-2/SJ.

Interpretacja indywidualna $\mathrm{z}$ dnia 20 maja 2016 r., IPPB1/4511-211/16-2/KS.

Interpretacja indywidualna z dnia 12 września 2017 r., 0113-KDIPT2-1.4011.220.2017.1.ISL.

Interpretacja indywidualna $z$ dnia 2 października 2017 r., 0111-KDIB1-1.4011.129.2017.1.BK.

Interpretacja indywidualna $z$ dnia 8 grudnia 2017 r., 0113-KDIPT2-1.4011.359.2017.1.AP.

Odpowiedź na interpelację nr 33692 z dnia 26 sierpnia 2015 r.

Puślecki D., Prawne pojęcie gospodarstwa rodzinnego, „Roczniki Naukowe Stowarzyszenia Ekonomistów Rolnictwa i Agrobiznesu" 2016, nr 18(2).

Szlęzak-Matusewicz J., Zarządzanie podatkami osób fizycznych, WoltersKluwer, Warszawa 2013.

Szlęzak-Matusewicz J., Zarządzanie ryzykiem podatkowym w przedsiębiorstwie, „Studia i Prace Kolegium Zarzadzania i Finansów" 2008, nr 86.

Ustawa z dnia 26 lipca 1991 r. o podatku dochodowym od osób fizycznych (Dz.U. 2018, poz. 200).

Ustawa z dnia 29 września 1994 r. o rachunkowości (t.j. Dz.U. 2016, poz. 1047 ze zm.).

Ustawa z dnia 29 sierpnia 1997 r. - Ordynacja podatkowa (Dz.U. 2017, poz. 201).

Ustawa z dnia 11 kwietnia 2003 r. o kształtowaniu ustroju rolnego (Dz.U. 2016, poz. 2052).

Ustawa z dnia 9 kwietnia 2015 r. o zmianie ustawy o podatku dochodowym od osób fizycznych oraz niektórych innych ustaw (Dz.U. poz. 699 ze zm.).

Wyrok NSA z dnia 17 czerwca 2009 r., sygn. II FSK 289/08.

\section{Tax Optimization of Special Branches of Agricultural Production}

The tax on agricultural farms is the agricultural tax, which depends primarily on the usable value of land. The only exception is the so-called special branches of agricultural production. On the basis of personal income tax, they constitute a separate source of income that can be taxed in two ways: based on real income or based on estimated income. The latter method is extremely favorable for taxpayers. Starting from 2016, there has been a change in the regulations regarding the taxation of special branches of agricultural 
production. They were subject to the requirement to keep accounting books in the situation described in the accounting regulations. In practice, this means losing the ability to determine income based on estimates. The aim of the article is to indicate the possibility of optimizing the taxation of special branches of agricultural production and risks related to the activity of taxpayers in this area. The achievement of the adopted objective will be possible thanks to the analysis of the legal structures of the Personal Income Tax Act and the Accounting Act and the judgments of tax authorities and administrative courts in Poland.

\section{Optymalizacja opodatkowania działów specjalnych produkcji rolnej}

Podatkiem obciążającym gospodarstwa rolne jest podatek rolny. Jego wymiar zależy przede wszystkim od wartości użytkowej ziemi. Wyjątkiem są tzw. działy specjalne produkcji rolnej. Na gruncie podatku dochodowego od osób fizycznych stanowią one odrębne źródło przychodów, które może być opodatkowane na dwa sposoby: w oparciu o dochód rzeczywisty lub w oparciu o dochód szacunkowy. Począwszy od 2016 r., nastąpiła zmiana przepisów w zakresie opodatkowania działów specjalnych produkcji rolnej. Działalność ta została bowiem objęta wymogiem prowadzenia ksiąg rachunkowych w sytuacji osiągnięcia określonej w przepisach o rachunkowości wielkości przychodów. W praktyce oznacza to utratę możliwości ustalania dochodu w oparciu o normy szacunkowe, które są niezwykle korzystne dla podatników. Celem artykułu jest wskazanie możliwości optymalizacji opodatkowania działów specjalnych produkcji rolnej i ryzyk związanych z działaniem podatników w tym zakresie. Osiągnięcie przyjętego celu możliwe będzie dzięki analizie konstrukcji prawnych ustawy o podatku dochodowym od osób fizycznych i ustawy o rachunkowości oraz orzecznictwa organów podatkowych i sądów administracyjnych. 